\title{
Rape Myths in Rapists and Other Offenders
}

\author{
Justina W. Aranha Fernandes ${ }^{1}$, Dr. Nandini Sanyal ${ }^{2} *$, Brahmini Goud ${ }^{3}$, \\ Prof. Saroj Arya ${ }^{4}$
}

\section{ABSTRACT}

Rape is a commonly occurring International phenomenon which has no cultural boundaries. Rape is a pervasive crime (Grubb, 2008; Harrower, 2009) and is significant due to its huge social and personal cost to the victims, their families and eventually society as a whole (Polaschek, Ward \& Hudson, 1997). Rape in India has been described as one of India's most common crimes against women. The objective of this study was to determine whether there is a significant difference between rapists and other-offenders with respect to rape myths and its 7 dimensions (viz., 'she asked for it', 'it wasn't really rape', 'he didn't mean to', 'she wanted it', 'she lied', 'rape is a trivial event' and 'rape is a deviant event'). A non-probability purposive sampling method was employed to select a sample of 60 male prisoners who were convicted and sentenced. Among them, 30 were rapists and 30 were other-offenders. The Illinois Rape Myth Acceptance Scale (IRMA) (Payne, Lonsway \& Fitzgerald, 1999) was used to measure the rape myths prevalent among rapists and other-offenders. The results revealed that there is a significant difference between rapists and other-offender with respect to rape myths and its 7 dimensions. Studies such as this draw attention to how we as a society responsible for introducing such appalling levels of violence against women, which is being endured, tolerated and even regularised. More laws or pleas for death sentences are not the answer to this deep-rooted societal problem. What is required today is not more protection and security, but education about rape and the motive behind such a monstrous crime and its implications.

Keywords: Rape, Rapists, Offenders

The occurrence of sexual assault including rape has been discussed quite thoroughly since the 1980s (Girard \& Senn, 2008). Rape as a subject has received immense academic attention as a result of its pervasive occurrence and impact. Rape is a commonly occurring International

\footnotetext{
${ }^{1}$ Research Scholar, Mewar University, Rajasthan, India

${ }^{2}$ Asst. Prof., Dept. of Psychology, St. Francis College for Women, Begumpet, Hyderabad, India

${ }^{3}$ Graduate Student, St. Francis College for Women, Begumpet, Hyderabad, India

${ }^{4}$ Research Supervisor, Mewar University, Rajasthan, India

*Corresponding Author

(C) 2016, J Fernandes, N Sanyal, B Goud, S Arya; licensee IJIP. This is an Open Access Research distributed under the terms of the Creative Commons Attribution License (http://creativecommons.org/licenses/by/2.0), which permits unrestricted use, distribution, and reproduction in any Medium, provided the original work is properly cited.
} 


\section{Rape Myths in Rapists and Other Offenders}

phenomenon which has no cultural boundaries. Sexually aggressive behavior seems to be embedded in the modern society (Grubb \& Turner, 2010). Rape is a pervasive crime (Grubb, 2008; Harrower, 2009). Rape is significant due to its huge social and personal cost to the victims, their families and eventually society as a whole (Polaschek, Ward \& Hudson, 1997). The UN Crime Trends Survey questionnaire defines rape as 'sexual intercourse without valid consent.' The term 'rape' is deeply rooted in our cultural lexicon and has great evocative and graphic qualities. It stirs up feelings of fear and antipathy as it is essentially about people who sexually force themselves up on others, often in violent ways (Burt, 1980). Rape is a crime, it is not sexual intercourse.

Rape in India has been described as one of India's most common crimes against women (Kumar, 1993). Women hold a high status in the Indian society, but there are no strict measures in place to protect them. Though the Indian Constitution enlists various laws to protect women there are many loop holes (Sashu, 2011). The Indian Penal Code defines rape as sexual intercourse or penetration by a man, without the consent of a woman (Krishnawat, Legal Service India). According to Justice Doraiswami Raju and Justice Arijit Pasyat (2005), "Rape is not only against the person of a woman; it is a crime against the entire society. It destroys the entire mindset of a woman and pushes her into deep emotional crisis"' (Karimattam, 2005). A rape victim is injured both physically and emotionally (Giri, 2006). Research states that rape emotionally damages the victims (Buddie \& Miller, 2001). Women who have been ra ped are more depressed and anxious than non-victimized women (Kilpatrick, Resick \& Veronen, 1981). According to the United Nations statistics, India has a high rape rate (Harrendorf, Heiskanen \& Malby, 2010). It is estimated that 1 in every 4 women will be the victim of rape in their lifetime and up to $45 \%$ of collegiate women have endured some form of sexual assault scenes leaving High School (De Keseredy \& Kelly, 1993; DeKeseredy \& Kelly, 1995). The World Health Organization 2012 states that the principal factors that lead to perpetration of sexual violence are: beliefs in family honor and sexual purity, ideologies of male sexual entitlement and weak legal sanctions for sexual violence.

Groth and Birnbaum (1979) identified three different kinds of rapists: anger rapist, power rapist and sadist rapist. The first type of rapist is anger rapist. Anger rapists are very angry men. Even though they may be angry at women in general, or may react angrily to specific behavior of their victim, they are most often angry about a variety of issues in their lives. They cannot and will not face the complicated issues in their life directly and in a pro social manner. Angry rapists are more likely to use a significant amount of physical force when they subdue their victims- in most cases, far more force than is needed to perpetrate the abuse. This often leaves victims severely beaten and injured on different areas of the bodies. Anger rapists also have a tendency to be verbally abusive during their attack- which is short in duration and very explosive in nature. Anger rapists do not tend to plan their specific offenses. Rather, they act impulsively to take advantage of situations. Victim choice depends wholly up on whom anger rapists see as 


\section{Rape Myths in Rapists and Other Offenders}

vulnerable and available at the moment they decide they want to offend. Between $25 \%$ and $40 \%$ of known rapes are committed by men who are considered anger rapists. Second type of rapist is the powers rapist. Power rapists- like anger rapists- use sexual assault as a means to feel powerful and in control. They do not however discharge anger during their offences and they only use physical force necessary to perpetrate the offense. If power rapist can gain control through threat and psychological coercion (rather than physical intimadation) they will do so. As a result the physical injuries usually associated with anger rapists are less common with power rapists. The offences themselves may last over a long period of time than those committed by angry rapists and maybe repetitive in nature. Domestic violence offenders who commit sexual assault against the partners are often power rapists. Finally, sadistic rapists are individuals who have an erotic attraction to power, anger or violence. Sadistic rapists engage in compulsive, sometimes ritualized sexual assault behavior. Because they have an erotic response to power and control, extreme violence and torture often characterize their assaults. In many cases victims of sadistic rapists are murdered during the assault. Unlike all the other types of sex offenders, sadistic rapists often have a very significant psychiatric difficulty that may have a direct relationship to the offence behavior.

Rape myths influence the common perception of rape (Burt, 1980, 1991). Rape myths are false beliefs, which are used primarily to shift the blame of rape from the perpetrators to victims. They are prevalent in today's society and in many ways contribute towards the incidence of rape (Suarez \& Gadalla, 2010). They are false beliefs, prejudices or stereotypes about the act of rape, the rape victims or the rapists. Rape myths are a part of the general culture. They are acquired from the family, friends, newspapers, movies, books, dirty jokes etc (Odem \& Clay-Warner, 1998). The acceptance of rape myths is linked with factors such as gender role labelling, sexual conservatism and acceptance of interpersonal aggression (Burt, 1980). Lonsway and Fitzgerald (1994) define rape myths as 'Attitudes and beliefs that are generally false but are widely and persistently held and that serve to deny and justify male sexual aggression against women.' Koss (1993) opines that rape myths can be categorized under 3 headings: victim masochism (e.g., they enjoy or they want it), victim fabrication (e.g., they lie or exaggerate) and victim precipitation (e.g., they ask for or they deserve it, happens to certain types of women). Belief in such myths may allow men to justify male sexual violence and women to deny personal vulnerability to rape (Lonsway \& Fitzgerald, 1995). Rape myths facilitate the denial of instances of rape. In a world without rape every act of coerced sex involving penetration would be understood and considered as rape (Burt, 1980, 1991). The just world theory is one of the fundamental explanations for the maintenance of rape myths (Lerner, 1980; Lerner \& Miller, 1978). According to the just world theory, people get what they deserve and deserve what they get. By attributing the blame on victims, one's perceived probability of becoming a victim is lessened. This theory helps in

preserving the notion that the world is safe and secure place and the event such as rape can be controlled (Idisis, Ben-David \& Ben-Nauchum, 2007). 


\section{Rape Myths in Rapists and Other Offenders}

Rape is generally considered as a sexual crime against women and the rape of men is neglected (Stermac, Sheridan, Davidson \& Dunn, 1996; Walker, Archer \& Davies, 2005). But, of late a large number of male rapes have been reported (Shechory \& Idisis, 2006). Regardless of these findings, people fail to recognize the rising numbers of men who are sexually assaulted (Anderson, 1982). Research suggests that rape myths about men, such as 'a male rape victim who showed no resistance to his attacker should have done so' exist (Kassing \& Preito, 2003) and 'sexual assault against men typically occur only in prisons or other institutional settings' (Shechory \& Idisis, 2006). Thus, usually rape myths have been discussed in the perspective of violence against women (Shechory \& Idisis, 2006).

Social acceptability rules are stricter for women than for men (Williams \& Best, 1994), hence, the behavior of female rape victims is blamed more than the behavior of male victims (Schneider, Ee \& Aronson, 1994). There are fewer acceptances of rape myth about men (Struckman-Johnson \& Struckman -Johnson, 1992). Authorities, public, rapists and even victims themselves often attribute blame to the victim (Wakelin \& Long, 2003). Greater is the acceptance of rape myths when greater is the willingness to attribute the blame to victims of sexual assault (Kooper, 1996). Thus, more the rape myths people believe in, more is the tendency to blame the victim and more is the likelihood that people will believe that rape victim is responsible for her/his victimization (Shechory \& Idisis, 2006).

Generally, when women are the rape victims, it has been found that women as well as men have different rape myths, although the necessity that these beliefs serve be different. Men use them to justify sexual aggressiveness, while women use them to deny personal vulnerability to rape (Johnson et al., 1997). At the same time researchers have stated that men have a more prominent tendency to adopt and endorse rape myths, to blame the rape victim and to view the rapist with a higher degree of lenience (Idisis, Ben-David, \& Ben-Nachum, 2007). This may perhaps reflect defensive attributions; it could suggest that individuals tend to blame the victims who are not similar to them (Shaver, 1970). Most rape victims are women, so men may feel different from this particular group of victims and thus are more likely to support rape myths than women (Giacopassi \& Dull, 1986; Gilmartin-Zena, 1988). Rape myths allow perpetrators to justify the sexually violent behaviour and permit non perpetrators to express hostile sexism by justifying the perpetrator's behaviour. Rape myths that blame the victim reinforce men's beliefs that the perpetrator was merely responding to a woman's sexual invitations (from her clothing, flirtatious behaviour, decision reputation, etc.). Therefore, victims and perpetrators, as well as third parties are motivated to employ rape myths.

People hold an idea of what the 'real' rape is. When they hear of a specific incident in which a woman is raped, they look at the incident, compare it to the idea of 'real' rape and often decide that the woman was not 'really' raped. The Classic 'real' rape, for many people, is raped by a stranger to use as a weapon; it is an attack which happens at night, it happens outside (in a dark 


\section{Rape Myths in Rapists and Other Offenders}

passageway), it occurs with a lot of violence, there is resistance by the victim and hence severe wounds and signs of struggle are visible (Burt, 1980). In fact, most of the above mentioned elements are absent in the majority of rape incidences. More than half of the rapes are committed by someone known to the victim; most do not involve a weapon, or injury beyond minor bruises or scratches, most occur indoors in either the victim's or the assailants' home (Burt, 1998). Rape myths, thus, are the mechanism that people use to justify dismissing an incident of sexual assault from the category of 'real rape.' Accepting or believing rape myths lead to a more restrictive definition of rape, which is rape-supportive because such thinking denies the reality of many actual rapes. Rejecting the assault as not been 'real' rapes makes the prosecution harder, the victim's recovery more difficult and the assailant's actions safer. Rejecting or disbelieving rape myths has the opposite effect; it leads to inclusion of more solids examples within the definition of what is a real rape (Burt \& Albin, 1981). The consequences for the victims of unreal rape are: people blame them, treat them badly, do not take their situation seriously and do not offer needed support (Burt \& Estep, 1981).

The gruesome gang rape in Delhi (December, 2012) has outraged us to say the least (Kidvai, 2012). Rape is not only about deranged individuals or infringement of law and order. Nor is the problem going to be solved by having more laws, more police on our streets, more CCTV cameras or stricter sentences for rapists. Rapes in India are increasing at an alarming rate. This has compelled us to reflect upon who we are as a society. Indians need to understand that rape is not just a heinous crime committed by heartless men. We need to address how we as a society responsible for introducing such appalling levels of violence against women, which is being endured, tolerated and even regularised. More laws or pleas for death sentences are not the answer to this deep-rooted societal problem. What is required today is not more protection and security, but education about rape and the motive behind such a monstrous crime and its implications. Hence the present study aims to ascertain the rape myths which act as an impetus to a ghastly crime like rape.

\section{Objectives}

- To determine whether there is a significant difference between rapists and otheroffenders with respect to rape myths and its 7 dimensions (viz., 'she asked for it', 'it wasn't really rape', 'he didn't mean to', 'she wanted it', 'she lied', 'rape is a trivial event' and 'rape is a deviant event').

\section{Hypotheses}

H1. There is a significant difference between rapists and other-offenders with respect to rape myths.

H2. There is a significant difference between rapists and other-offenders with respect to the 'she asked for it' dimension of rape myths. 


\section{Rape Myths in Rapists and Other Offenders}

H3. There is a significant difference between rapists and other-offenders with respect to the 'it wasn't really rape' dimension of rape myths.

H4. There is a significant difference between rapists and other-offenders with respect to the 'he didn't mean to' dimension of rape myths.

H5. There is a significant difference between rapists and other-offenders with respect to the 'she wanted it' dimension of rape myths.

H6. There is a significant difference between rapists and other-offenders with respect to the 'she lied' dimension of rape myths.

H7. There is a significant difference between rapists and other-offenders with respect to the 'rape is a trivial event' dimension of rape myths.

H8. There is a significant difference between rapists and other-offenders with respect to the 'rape is a deviant event' dimension of rape myths.

\section{METHOD}

\section{Research Design}

The present research is a quantitative study which adopts a between-groups design to determine whether there is a significant difference between rapists and other-offenders with respect to rape myths and its 7 dimensions (viz., 'she asked for it', 'it wasn't really rape', 'he didn’t mean to', 'she wanted it', 'she lied', 'rape is a trivial event' and 'rape is a deviant event').

\section{Participants}

A non-probability purposive sampling method was employed to select a sample of 60 male prisoners who were convicted and sentenced. Among them, 30 were rapists and 30 were otheroffenders. The data was collected from Chanchalguda and Cherlapally jail from the metropolitan city of Hyderabad.

\section{Inclusion Criteria}

1. Rapists and other-offenders between the age of 18 and 60 were included in this sample.

2. Rapists and other-offenders convicted and sentenced for a crime committed were included in this sample.

\section{Exclusion Criteria}

1. Rapists and other-offenders diagnosed of having any psychotic disorders were not included in this sample.

\section{Instrument}

The Illinois Rape Myth Acceptance Scale (IRMA) developed by Payne, Lonsway and Fitzgerald (1999) was used to measure the rape myths prevalent among men about women as victims of rape. It consists of 45 items. It has 7 dimensions (viz., 'she asked for it', 'it wasn't really rape', 'he didn't mean to', 'she wanted it', 'she lied', 'rape is a trivial event' and 'rape is a deviant 


\section{Rape Myths in Rapists and Other Offenders}

event'). It is a 5 point Likert scale ranging from (1) 'Strongly agree' to (5) 'Strongly Disagree'. Higher scores indicate higher rejection of rape myths. Higher the score in each dimension lower the inclination towards that dimension. The coefficient alpha of this scale is 0.95.

\section{Procedure}

After selecting the measures, a few arrangements were made for data collection. The questionnaires and the Information Schedule were prepared and organized. The study was initiated after taking due permission and consent from the Cherlapally and Chanchalguda Jail. The researcher took permission from respective jails and went for collecting the data on scheduled dates. Informed consent was taken from the rapists and other-offenders and the questionnaire was administered. In addition to the written instructions, they were also instructed verbally and were encouraged to seek clarification on any aspect related to the study. On an average the time taken to administer the scale was 15 minutes.

\section{Statistics Used}

Mean, Standard Deviation and t test were the statistics used to draw inferences from the data.

\section{RESULTS}

Table 1: Means, Standard Deviations and t-ratios of Rapists and Other-Offenders for Rape Myths and its seven dimensions.

\begin{tabular}{|c|c|c|c|c|c|}
\hline Variable & $\mathrm{N}$ & $\begin{array}{l}\text { Type of } \\
\text { Offenders }\end{array}$ & Mean & $\begin{array}{l}\text { Standard } \\
\text { Deviation }\end{array}$ & t-ratio \\
\hline \multirow{2}{*}{ Rape Myth } & 30 & Rapists & 73.33 & 9.54 & \multirow{2}{*}{$16.00^{* * * *}$} \\
\hline & 30 & Others & 128.53 & 16.32 & \\
\hline \multirow{2}{*}{ She asked for it } & 30 & Rapists & 14.10 & 2.50 & \multirow{2}{*}{$11.73^{* * * *}$} \\
\hline & 30 & Others & 25.20 & 4.54 & \\
\hline \multirow{2}{*}{ It wasnỖt really rape } & 30 & Rapists & 9.20 & 1.86 & \multirow{2}{*}{$10.48^{* * *}$} \\
\hline & 30 & Others & 16.80 & 3.51 & \\
\hline \multirow{2}{*}{$\mathrm{He}$ didnỐt mean to } & 30 & Rapists & 9.50 & 1.98 & \multirow{2}{*}{$10.50^{*-*}$} \\
\hline & 30 & Others & 15.70 & 2.56 & \\
\hline \multirow{2}{*}{ She wanted it } & 30 & Rapists & 8.80 & 1.90 & \multirow{2}{*}{$10.62^{* * * *}$} \\
\hline & 30 & Others & 15.93 & 3.15 & \\
\hline \multirow{2}{*}{ She lied } & 30 & Rapists & 9.00 & 1.68 & \multirow{2}{*}{$10.63^{\text {*k*k }}$} \\
\hline & 30 & Others & 15.93 & 3.15 & \\
\hline \multirow{2}{*}{$\begin{array}{c}\text { Rape is a trivial } \\
\text { event }\end{array}$} & 30 & Rapists & 9.66 & 1.79 & \multirow{2}{*}{$9.74^{* * * *}$} \\
\hline & 30 & Others & 16.70 & 3.53 & \\
\hline \multirow{2}{*}{$\begin{array}{c}\text { Rape is a deviant } \\
\text { event }\end{array}$} & 30 & Rapists & 13.06 & 2.08 & \multirow{2}{*}{$11.25^{* k *}$} \\
\hline & 30 & Others & 22.26 & 3.96 & \\
\hline
\end{tabular}

$* *_{p}<0.01$ 


\section{Rape Myths in Rapists and Other Offenders}

Table 1 reveals that there is a significant difference between rapists and other-offenders with respect to rape myths $(\mathrm{p}<0.01)$. It is evident from the mean scores in table 1 that the rapists $(\mathrm{M}=$ 73.33) scored lower on rape myths when compared to other-offenders $(M=128.53)$. As described earlier, on the Illinois Rape Myth Acceptance Scale, higher the score in each dimension lower the inclination towards that dimension. In other words, rejection of rape myths was higher in other-offenders as compared to rapists. Further analysis revealed significant differences between rapists and other-offenders with respect to the dimensions of 'She asked for it' $(\mathrm{p}<0.01)$, 'It wasn't really rape' $(\mathrm{p}<0.01)$, 'He didn't mean to' $(\mathrm{p}<0.01)$, 'She wanted it' $(p<0.01)$, 'She lied' $(p<0.01)$, 'Rape is a trivial event' $(p<0.01)$, and 'Rape is a deviant event' $(p<0.01)$ of rape myths. It is evident from the mean scores in Table 1 that the rapists $(M=14.10)$ scored lesser than the other-offenders $(M=25.20)$ on the dimension 'She asked for it' of rape myths. In other words, rejection of the 'she asked for it' rape myth was higher in other-offenders when compared to rapists. Likewise, it is evident from the mean scores that the rapists ( $\mathrm{M}=$ 9.20) scored lesser than the other-offenders $(M=16.80)$ on the dimension 'It wasn't really rape' of rape myths. In other words, rejection of the 'it wasn't really rape' rape myth was higher in other-offenders when compared to rapists. The mean scores in Table 1 also indicate that the rapists $(M=9.50 ; M=8.80 ; M=9.90)$ scored lesser than the other-offenders $(M=15.70 ; M=$ 15.93; $M=15.93$ ) on the rape myth dimensions of 'He didn't mean to,' 'She wanted it' and 'She lied' respectively. In other words, rejection of these rape myths was higher in other-offenders when compared to rapists. Lastly, it is evident from the mean scores that the rapists $(M=9.66$; $M=13.06)$ scored lesser than the other-offenders $(M=16.70 ; M=22.26)$ on the dimensions of 'Rape is a trivial event' and 'Rape is a deviant event' respectively. In other words, rejection of 'rape is a trivial event' and 'rape is a deviant event' rape myths were higher in other-offenders when compared to rapists. Thus, hypotheses $\mathrm{H} 1$ - H8 were accepted.

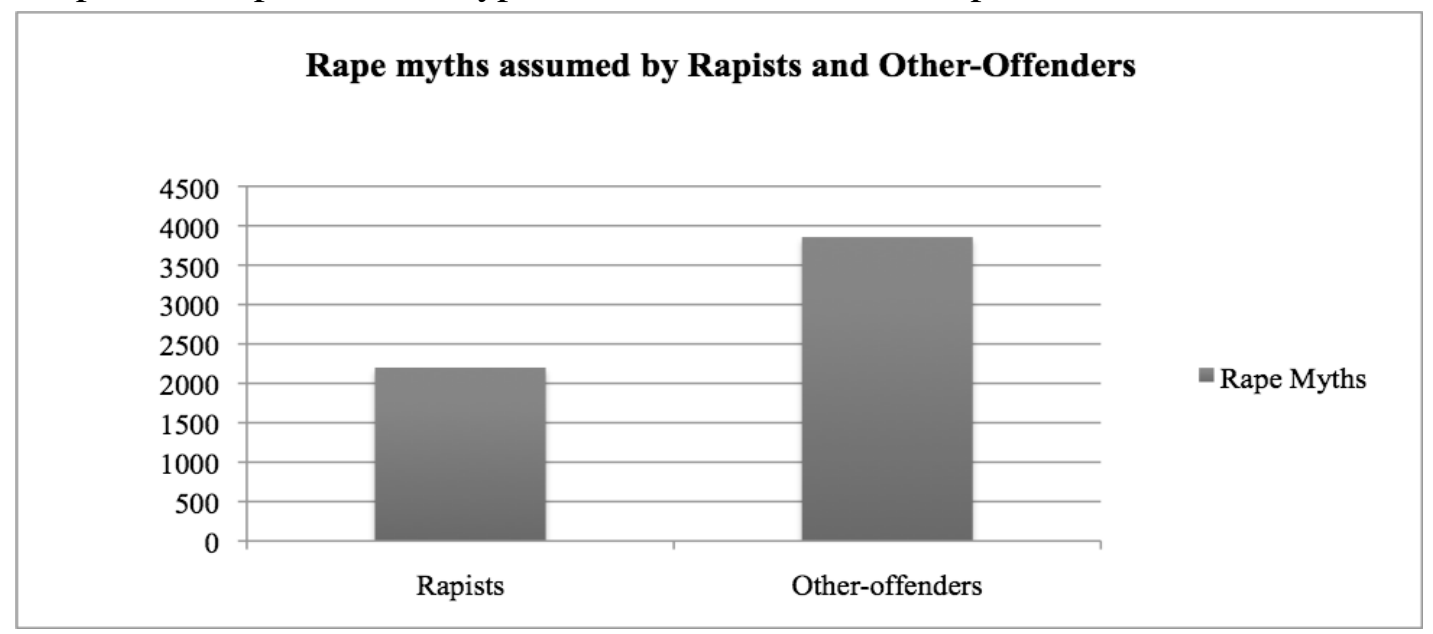

Note: Higher scores indicate greater rejection of rape myths. Lower scores indicate greater acceptance of rape myths

Figure 1: Rape myths assumed by rapists and other-offenders: she asked for it, it wasn't really rape, he didn't mean to, she wanted it, she lied, and rape is trivial event. 

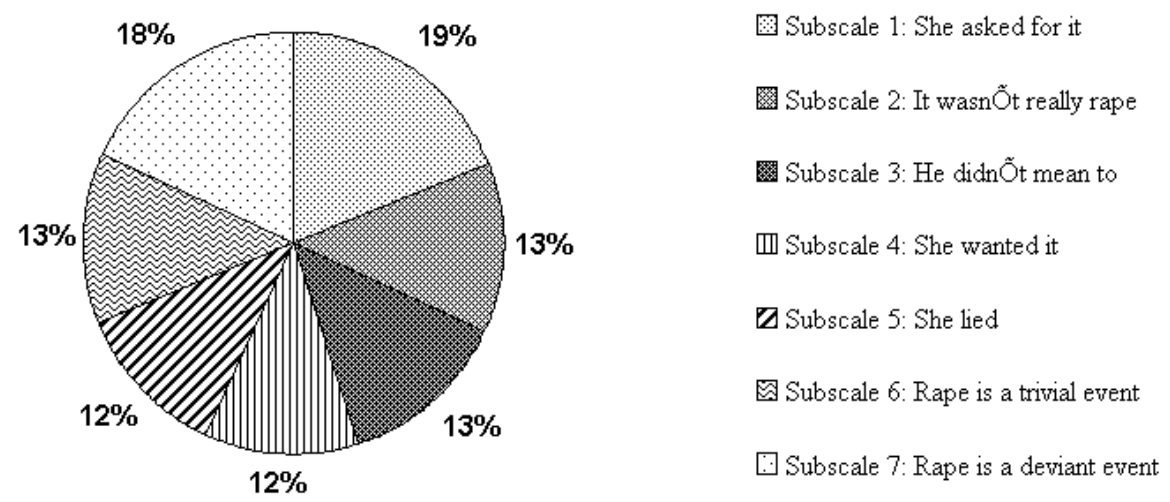

Figure 2: Rape myths assumed by rapists: she asked for it, it wasn't really rape, he didn't mean to, she wanted it, she lied, and rape is trivial event.

\section{Rape Myths Assumed By Other Offenders}
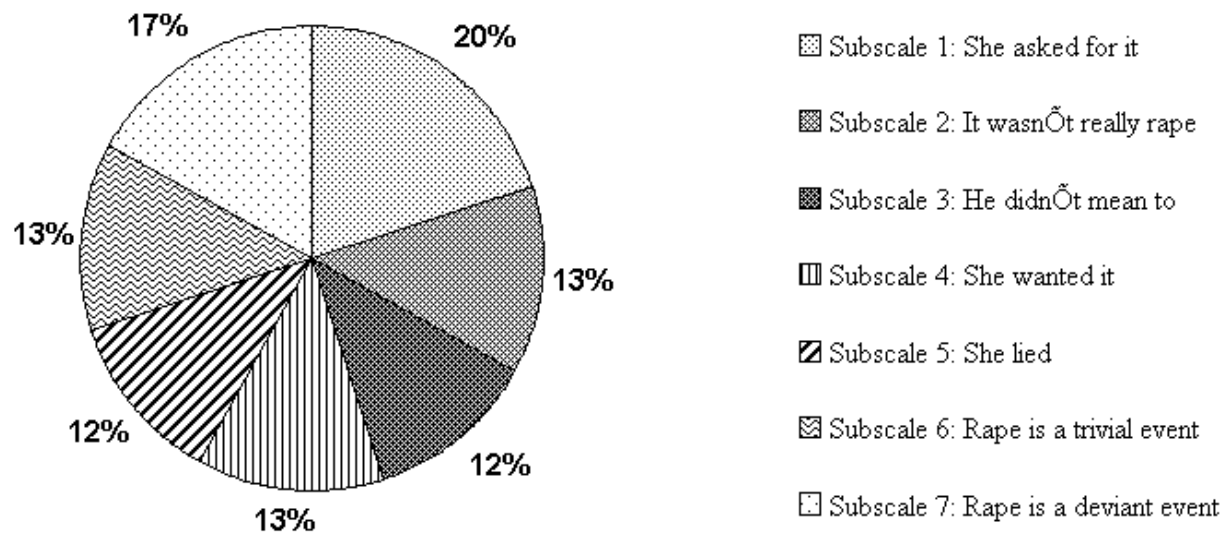

Figure 3: Rape myths assumed by Other-offender: she asked for it, it wasn't really rape, he didn't mean to, she wanted it, she lied, and rape is trivial event.

\section{DISCUSSION}

The analysis of the results of the present study revealed that there is a significant difference between rapists and other-offenders with respect to rape myths. It is apparent that the rejection of rape myths was higher in other offenders when compared to rapists. According to the social learning theory of rape, rape myths are the chief causes of rape. Rape myths allow perpetrators to justify their sexually violent behaviour and permit non-perpetrators to express hostile sexism by justifying the perpetrators behaviour. Rape myths that blame the victim reinforce men's beliefs that the perpetrator was merely responding to a woman's sexual invitations (from her clothing,

(c) The International Journal of Indian Psychology, ISSN 2348-5396 (e)| ISSN: 2349-3429 (p) | 80 


\section{Rape Myths in Rapists and Other Offenders}

flirtatious behaviour, sexual reputation, etc). Therefore, victims and perpetrators, as well as third parties are motivated to employ rape myths (Franuik, Seefelt \& Vandello, 2008).

The findings also indicated that the rejection of rape myth 'she asked for it' was higher in other offenders when compared to rapists. According to Koss (1993) rape myths can be listed under 3 topics; the first one is victim precipitation (for e.g., they ask for/deserve it, it only happens to certain types of women). According to Shechory \& Idisis, 2006, many women wish to be raped. Field (1978) is of the opinion that people who advocate traditional attitudes believe that women are to be blamed for rape. According to Wakelin and Long (2003), authorities, public, rapists and even victims themselves often attribute blame to the victim. Greater is the acceptance of rape myths when greater is the willingness to attribute blame to the victims of sexual assault. Thus, more the rape myths people believe in, more is the tendency to blame the victim and more is the likelihood that people will believe the rape victim is responsible for his or her victimization (Shechory \& Idisis, 2006). When people attitude blame to victims, they place them under scrutiny; and factors such as the victims’ dress (Kanekar \& Kolsawalla, 1980), respectability and attractiveness are used to establish the extent to which a victim must be held responsible for the rape. Kanekar and Kolsawalla (1980) are of the opinion that if the victim was dressed provocatively, then she will be made responsible for the rape. Even normal social behaviours can be perceived as contributory factor in the victims rape - for example, a victim who had a drink on her own before her rape, received more blame for her attack than a woman who finished work in the office before her rape (Krahe, 1988), even though, in both cases there is no clear suggestion that the victim behaviour was related to the attack in anyway.

The study reported significant differences between rapists and other-offenders with respect to the 'it wasn't really rape' and 'he didn't mean to' dimensions of rape myths. It is apparent that the rejection of the rape myths 'it wasn't really rape' and 'he didn't mean to' was higher in other offenders when compared to rapists. According to Burt (1980), Costin and Schwars (1987), Ehrhart and Sandler (1985) and Lonsway and Fitzgerald (1994), 'Victims of failed to report to the police right away were not really raped' is a common rape myth. Likewise, Brownmiller (1975) and Burt (1980) argue that some societies are 'rape-supportive' because victims are held somewhat responsible for their sufferings; whereas perpetrators are usually excused and their actions are partly justified, Williams and Best (1994) opine that social acceptability rules are stricter for women than men. Hence, behaviour of female rape victims is blamed more than the behaviour of male victims (Schneider, Ee \& Aaronson, 1994). At the same time, researchers have stated that men have a more prominent tendency to adopt and endorse rape myths, to blame the rape victim and view the rapist with the higher degree of lenience (Idisis \& Ben-David, 2007).

Moreover, the analysis of the present findings revealed a significant difference between rapists and other-offenders with respect to the 'she wanted it' and 'she lied' dimensions of rape myths. 


\section{Rape Myths in Rapists and Other Offenders}

It is apparent that the rejection of the rape myths 'she wanted it' and 'she lied' was higher in other offenders when compared to rapists. These results are supported by the findings of a previous study by Koss (1993) which suggested that one of the most commonly reported rape myth is victim machoism (e.g., they enjoy or they want it).

Lastly, the present study found significant differences between rapists and other-offenders with respect to the 'rape is a trivial event' and 'rape is a deviant event' dimensions of rape myths. In other words, the results suggested that as compared to the rapists, the rejection of the rape myths 'rape is a trivial event' and 'rape is a deviant event' was higher in other offenders. According to Johnson et al., (1997) generally, when women are the rape victims it has been found that women as well as men have different rape myths, although the necessity these beliefs serve maybe different. While women use them to deny personal vulnerability to rape, men use them to justify sexual aggressiveness.

It can be observed from figure 2 that there is not much difference between the rape myths assumed by rapists. Rapists assume the rape myth: 'She asked for it' $19 \%$ of the time; the rape myth: 'rape is a deviant event' $18 \%$ of the time; the rape myth: 'it wasn't really rape', 'he didn't mean to' and 'rape is a trivial event' $13 \%$ of the time; and the rape myth: 'she wanted it' and 'she lied' $12 \%$ of the time. It can be observed from figure 3 that there is not much difference between the rape myths assumed by other-offenders. Other-offenders assume the rape myth: 'She asked for it' $20 \%$ of the time; the rape myth: 'rape is a deviant event' $17 \%$ of the time; the rape myth: 'it wasn't really rape', 'he didn't mean to' and 'rape is a trivial event' $13 \%$ of the time; and the rape myth: 'she wanted it' and 'she lied' $12 \%$ of the time. Thus, rape myths influence the common perception of rape (Burt, 1980, 1991). Rape myths facilitate in the denial of instances of rape. In a world without rape, every act of coerced sex involving penetration would be understood and considered as rape (Burt, 1980, 1991). Thus, rape myths are the mechanism people use to justify dismissing an incident of sexual assault from the category of 'real rape'. Accepting or believing rape myths lead to a more restrictive definition of rape, which is rape-supportive because such thinking denies the reality of many actual rapes. Rejecting the assaults as not being 'real' rapes makes rape prosecution harder, the victim's recovery more difficult and the assailant's actions safer. Rejecting or disbelieving rape myths has the opposite effect; it leads to inclusion of more solid examples within the definition of what a real rape is (Burt \& Albin, 1981).

Rape myths are present in scores of individuals (Lonsway \& Fitzgerald, 1994). The empirical data supports the notion that rape myths are assumed by both rapists and other-offenders, but the degree is significantly high in rapists. Rapists assume rape myths more when compared to otheroffenders. We can infer that rape myths may be the driving force behind a horrendous crime like rape. Myths such as: 'she asked for it', 'it wasn't really rape', 'he didn't mean to', 'she wanted it', 'she lied', 'rape is a trivial event' and 'rape is a deviant event' may act as an impetus to an awful crime like rape. Rape myths allow perpetrators to justify their sexually violent behaviour 


\section{Rape Myths in Rapists and Other Offenders}

and permit non-perpetrators to express hostile sexism by justifying the perpetrators behaviour. Rape myths that blame the victim reinforce men's beliefs that the perpetrator was merely responding to a woman's sexual invitations (from her clothing, flirtatious behaviour, sexual reputation, etc). Therefore, victims and perpetrators, as well as third parties are motivated to employ rape myths. Ironically, the self-protective intention behind the use of rape myths can increase a woman's risk of being assaulted and can perpetuate cultural norms that trivialize rape (Franuik, Seefelt \& Vandello, 2008).

Rape can result in severe psychological and physical consequences for the victim. Hence, mental health professionals have outlined and adopted various treatment and preventive approaches so as to reduce and prevent rape recidivism and suffering of the victim (Marx, Miranda \& Meyerson, 1999). Based on the assumption that sexual offences like rape are a result of some unresolved developmental issues non-behavioral programs have laid emphasis on re-education, re-socialization and confrontation of unresolved life issues that cause sexually aggressive behavior. Although such approaches have been quite influential they lack the requisite empirical support, they neither give detailed treatment nor prevention significantly (Polaschek, Ward \& Hudson, 1997). Research suggests that adequate treatment would be necessary to deal with sexual crimes issues and to ensure that rapists do not re-offend (Ellis, 1983). Additionally, research recommends Cognitive skills training and Behavioral Conditioning as to treatment methods for rapists for reducing deviant sexual behavior (John Howard Society of Alberta, 2002). India could look into the possibility of introducing programs that provide treatment for rapists through an intensive course of therapy. Intervention in the form of treatment could include: psychotherapy, victim empathy, cognitive restructuring, anger management, relapse prevention, life planning and goal attainment and more. Research suggests that comprehensive treatment of sexual offenders can significantly reduce sexual offence recidivism (Studer, Reddon, Roper \& Estrada, 1996). This comprehensive approach has been tried and tested. Similar programs have been employed by many countries across the Globe, for example, The Phoenix Program at Alberta Hospital in Edmonton, Canada has proven to be very successful; and the recidivism rates for offenders treated by the program are low (John Howard Society of Alberta, 2002).

\section{Acknowledgments}

The author appreciates all those who participated in the study and helped to facilitate the research process.

\section{Conflict of Interests}

The author declared no conflict of interests.

\section{REFERENCES}

Ageton, S., (1983) Sexual assault among adolscents. Lexington: D. C. Health and Company. 


\section{Rape Myths in Rapists and Other Offenders}

Anderson, J. R. (1982). Acquisition of cognitive skill. Psychological review,89(4), 369Buddie, A. M., \& Miller, A. G. (2001). Beyond rape myths: A more complex view of perceptions of rape victims. Sex roles, 45(3-4), 139-160.

Burt, M. R. (1980). Cultural myths and supports for rape. Journal of personality and social psychology, 38(2), 217.

Burt, M. R., \& Albin, R. S. (1981). Rape myths, rape definitions, and probability of conviction. Journal of Applied Social Psychology, 11(3), 212-230.

Burt, M. R., \& Estep, R. E. (1981). Apprehension and fear: Learning a sense of sexual vulnerability. Sex Roles, 7(5), 511-522

De Keseredy, W. S., \& Kelly, K. (1995). Sexual abuse in Canadian university and college dating relationships: The contribution of male peer support. Journal of Family Violence, 10(1), 41-53.

DeKeseredy, W., \& Kelly, K. (1993). The incidence and prevalence of woman abuse in Canadian university and college dating relationships. Canadian Journal of Sociology/Cahiers canadiens de sociologie, 137-159.

Field, H. (1978). Attitides toward rape: a comparative analysis of police, rapists, crisis counselors and citizens. Journal of Personality and Social Pychology, Volume 36, 156-179.

Franiuk, R., Seefelt, J. L., \& Vandello, J. A., (2008). Prevalence of rape myths in headlines and their effects on attitudes toward rape, Sex Roles, Volume 58, 790-801.

Giacopassi, D. J., \& Dull, R. T. (1986). Gender and racial differences in the acceptance of rape myths within a college population. Sex Roles, 15(1-2), 63-75.

Gilmartin-Zena, P. (1988). Gender differences in students' attitudes toward rape. Sociological Focus, 21(4), 279-292.

Girard, A. L., \& Senn, C. Y. (2008). The role of the new "date rape drugs" in attributions about date rape. Journal of interpersonal violence, 23(1), 3-20.

Giri, V. M., ( 2006). Deprived Devis: Womens Unequal Status in Society. New Delhi: Gyan Publishing House

Groth, A. N., \& Birnbaum, A. H. (1979). Men who rape: The psychology of the oflender.

Grubb, A. R., \& Harrower, J. (2009). Understanding attribution of blame in cases of rape: An analysis of participant gender, type of rape and perceived similarity to the victim. Journal of Sexual Aggression, 15(1), 63-81.

Grubb, A., \& Turner, E. (2012). Attribution of blame in rape cases: A review of the impact of rape myth acceptance, gender role conformity and substance use on victim blaming. Aggression and Violent Behavior, 17(5), 443-452.

Harrendorf, S., Heiskanen, M., \& Malby, S. (2010). International Statistics on Crime. Development Research Group, World Bank.

Idisis, Y., Ben-David, S., \& Ben-Nachum, E. (2007). Attribution of blame to rape victims among therapists and non-therapists. Behavioral Sciences \& the Law, 25(1), 103-120.

Johnson, B. E., Kuck, D. L. \& Schander, P. R., (1997). Rape myths acceptance and sociodemographic characteristics: A multidimensional analysis. Sex Roles, Volume 36, 693-707. 


\section{Rape Myths in Rapists and Other Offenders}

Kanekar, S., \& Kolsawalla, M. B. (1980). Responsibility of a rape victim in relation to her respectability, attractiveness, and provocativeness. The Journal of social psychology, 112(1), 153-154.

Karimattam, M. (2005). Labouring Domestics and Domesticating Labour. Delhi: 2004 Justice and Peace Commission.

Kassing, L. R., \& Prieto, L. R. (2003). The Rape Myth and Blame-Based Beliefs of Counselors-in-Training Toward Male Victims of Rape. Journal of counseling \& development, 81(4), 455-461.

Kidvai, A. Z., (2012). Hanging Criminals won’t help reduce rape; education will. Tehelka Blog. Retrieved o January 8, 2013.

Kilpatrick, D. G., Resick, P. A., \& Veronen, L. J. (1981). Effects of a rape experience: A longitudinal study. Journal of Social Issues, 37(4), 105-122.

Kooper, B. A., (1996). Gender, Gender Identity, rape myth acceptance and time of initial resistance on the perception of acquaintance rape blame and avoidability, Sex Roles, Volume 34, 81-93

Koss, M. P. (1993). Detecting the scope of rape a review of prevalence research methods. Journal of interpersonal violence, 8(2), 198-222.

Krahé, B. (1988). Victim and Observer Characteristics as Determinants of Responsibility Attributions to Victims of Rape1. Journal of Applied Social Psychology, 18(1), 50-58.

Krishnavat, S. V. D., Redifining the Rape Laws in India: A Constructive and Comparative Approach. Legal Services India. Retrieved on December 15, 2012

Kumar, R. (1993). The History of Doing: An Account of Women's Rights and Feminism in India. New Delhi: Zubaan, 128.

Lerner, M. J., \& Miller. D. T., (1978). Just world research and the attribution process: Looking back and ahead. Psychology Bulletin, Volume 85, 1030-1051

Lerner, M. J., (1980). The belief in a just world: A fundamental delusion. New York: Plenum.

Lonsway, K. A., \& Fitzgerald, L. F. (1994). Rape myths in review. Psychology of women quarterly, 18(2), 133-164.

Lonsway, K. A., \& Fitzgerald, L. F. (1995). Attitudinal antecedents of rape myth acceptance: A theoretical and empirical reexamination. Journal of Personality and Social Psychology, 68(4), 704.

Marx, B. P., Miranda, R., \& Meyerson, L. A. (1999). Cognitive-behavioral treatment for rapists: can we do better?. Clinical Psychology Review, 19(7), 875-894.

Odem, M. E., \& Clay-Warner, J. (1998). Confronting rape and sexual assault(No. 3). Rowman \& Littlefield.

Polaschek, D. L., Ward, T., \& Hudson, S. M. (1997). Rape and rapists: Theory and treatment. Clinical Psychology Review, 17(2), 117-144.

Sashu, M., Change in definition of rape in India. Legal Services India. 


\section{Rape Myths in Rapists and Other Offenders}

Schneider, L. J., Ee, J. S. C., \& Aronson, H. (1994). Effects of victim gender and physical vs. psychological trauma/injury on observers' perceptions of sexual assault and its aftereffects. Sex Roles, 30(11-12), 793-808.

Shaver, K. G. (1970). Defensive attribution: Effects of severity and relevance on the responsibility assigned for an accident. Journal of Personality and Social Psychology, 14(2), 101.

Shechory, M., \& Idisis, Y. (2006). Rape myths and social distance toward sex offenders and victims among therapists and students. Sex Roles, 54(9-10), 651-658

Stermac, L., SHERIDAN, P. M., DAVIDSON, A., \& DUNN, S. (1996). Sexual assault of adult males. Journal of Interpersonal Violence, 11(1), 52-64.

Struckman-Johnson, C., \& Struckman-Johnson, D. (1992). Acceptance of male rape myths among college men and women. Sex Roles, 27(3-4), 85-100.

Studer, L. H., Reddon, J. R., Roper, V., \& Estrada, L. (1996). Phoenix: An in hospital treatment program for sex offenders. Journal of Offender Rehabilitation, 23(1-2), 91-97.

Suarez, E., \& Gadalla, T. M. (2010). Stop blaming the victim: A meta-analysis on rape myths. Journal of Interpersonal Violence, 25(11).

Wakelin, A., \& Long, K. M. (2003). Effects of victim gender and sexuality on attributions of blame to rape victims. Sex Roles, 49(9-10), 477-487.

Walker, J., Archer, J., \& Davies, M. (2005). Effects of rape on men: A descriptive analysis. Archives of sexual behavior, 34(1), 69-80.

Williams, J. E., \& Best, D. L. (1994). Cross-cultural views of women and men. Psychology and culture, 191-196.

How to cite this article: J Fernandes, N Sanyal, B Goud, S Arya (2016), Rape Myths in Rapists and Other Offenders, International Journal of Indian Psychology, Volume 3, Issue 4, No. 64, ISSN 2348-5396 (e), ISSN: 2349-3429 (p), DIP:18.01.122/20160304, ISBN: 978-1-365-32519-9 